\title{
Peningkatan Profesionalisme Guru PAI Melalui Kelompok Kerja Guru (KKG)
}

\author{
SARMADHAN LUBIS \\ Jurusan Pendidikan Agama Islam (PAI) STAI Tuanku Tambusai \\ Jl. Riau Pasir Pengaraian, Rambah, Kabupaten Rokan Hulu, Riau 28558 \\ e-mail: lubissarmadhan@gmail.com
}

\begin{abstract}
This paper aims to find out how to improve the professionalism of PAI teachers through Teachers Working Group (KKG). This paper is useful for teachers, the importance of following KKG PAI activities to improve the skills, skills, and profesionlaisme of teachers in the process of teaching and learning.First, Improving the professional ability of teachers PAI requires a container, for example for communication, information, discussion and coaching teachers PIE. Secondly, the improvement of Teacher KKG proficiency as a teacher is a teacher who master the characteristics of teaching materials and characteristics of learners. Characteristics of teaching materials include the concepts, principles, theories contained in teaching materials. Characteristics of learners include the potential, attitudes, interests, noble character, and personalities of learners. Third, Teacher Working Group PAI aims to Increase the sense of togetherness and responsibility as an Islamic religious educator who aims to instill faith (tauhid) and devotion to Allah SWT. Fostering the excitement of Islamic Religious Education Teachers to improve their skills and skills in preparing, implementing and evaluating the program of Teaching and Learning Activities (KBM) of Islamic Education.
\end{abstract}

Keywords: Improvement, Teacher Professionalism, Teacher Working Group

Abstrak: Tulisan ini bertujuan untuk mengetahui bagaimana peningkatan profesionalisme guru PAI Melalui Kelompok Kerja Guru (KKG). Tulisan ini bermanfaat bagi para guru, pentingnya mengikuti kegiatan KKG PAI untuk meningkatkan kemampuan, ketrampilan, dan profesionlaisme guru dalam proses belajar-mengajar. Pertama, Peningkatan kemampuan profesioanal guru PAI menuntut adanya wadah, antara lain untuk komunikasi, informasi, diskusi dan pembinaan sesama guru PAI. Kedua, Peningkatan kemampuan Guru KKG sebagai guru profesional adalah guru yang menguasai karakteristik bahan ajar dan karakteristik peserta didik. Karakteristik bahan ajar meliputi konsep, prinsip, teori yang terdapat dalam bahan ajar. Karakteristik peserta didik meliputi potensi, sikap, minat, akhlak mulia, dan personaliti peserta didik. Ketiga, Kelompok Kerja Guru PAI bertujuan untuk Meningkatkan rasa kebersamaan dan tanggung jawab sebagai pendidik agama islam yang bertujuan menanamkan keimanan (tauhid) dan ketaqwaan terhadap Allah SWT. Menumbuhkan kegairahan Guru PAI untuk meningkatkan kemampuan dan keterampilan dalam mempersiapkan, melaksanakan dan mengevaluasi program Kegiatan Belajar Mengajar (KBM) Pendidikan Agama Islam.

Kata Kunci: Peningkatan, Profesionalisme Guru, Kelompok Kerja Guru 


\section{PENDAHULUAN}

Dewasa ini makin tidak terasa perlunya manusia dibentengi dengan nilai-nilai luhur agama, mengingat pengaruhnya yang besar terhadap kehidupan manusia. Keduanya dapat menyeret manusia pada kelalaian, kealpaan dan lupa diri. Kelalaian dan kealpaan ini dapat disebabkan oleh kesibukan dalam rangka memenuhi tuntutan kebutuhan materi yang tak kunjung puas. Maka agama dan pengetahuan sebagai petunjuk hidup bagi manusia supaya tidak tersesat dalam menjalani kehidupan ini (Fuad Ihsan, 2005: 137).

Setiap guru profesional harus mengusai pengetahuan yang mendalam dalam sepesialisnya. Penguasaan pengetahuan ini merupakan syarat yang penting disamping keterampilanketerampilan lainnya. Oleh sebab itu dia berkewajiban menyampaikan pengetahaun, pengertian, keterampilan dan lain-lain kepada muridnya (Oemar Harnalik, 2007: 119).

Pentingnya

peningkatan kemampuan profesionalisme guru di Sekolah Dasar dapat ditinjau dari beberapa sudut pandang, ditinjau dari perkembangan ilmu pengetahuan dan tekhnologi pendidikan, kepuasan dan moral kerja, keselamatan kerja guru, dan peranannya yang demikian penting dalam rangka implementasi manajemen peningkatan mutu berbasis sekolah di Sekolah Dasar.

Peningkatan

kemampuan profesionalisme guru dapat diartikan sebagai sebagai upaya membantu guru yang belum matang menjadi matang, yang tidak mampu mengelola sendiri menjadi mampu mengelola sendiri, yang belum memenuhi kualifikasi menjadi memenuhi kualifikasi, yang belum terakreditasi menjadi terakreditasi. Peningkatan kemampuan profesional guru dapat juga diartikan sebagai upaya membantu guruyang belum profeisonal menjadi profesional. Yang mana hal-hal tersebut nantinya juga akan berpengaruh terhadap kualitas pembelajaran guru di sekolah.

Guru yang kreatif, profesional dan menyenangkan harus memiliki berbagai konsep dan cara untuk mendongkrak kualitas pembelajaran. Adapun beberapa cara yang dapat digunakan untuk mendongkrak kualitras pembelajaran antara lain dengan mengembangkan kecerdasan emosi (emotional quotient), mengembangkan kreativitas (creativity quotient) dalam pembelajaran, mendisiplinkan peserta didik dengan kasih sayang, membengkitkan nafsu belajar, memecahkan masalah, mendaya gunakan sumber belajar, dan melibatkan masyarakat dalam pembelajaran (E. Mulyasa, 2006: 161).

Peningkatan kemampuan Guru KKG sebagai guru profesional adalah guru yang menguasai karakteristik bahan ajar dan karakteristik pesreta didik. Karakteristik bahan ajar meliputi konsep, prinsip, teori yang terdapat dalam bahan ajar. Karakteristik peserta didik meliputi potensi, sikap, minat, akhlak mulia, dan personaliti peserta didik. Penguasaan karakteristik bahan ajar dan peserta didik diperlukan untuk menentukan metode dan strategi pembelajaran.

Selain itu karakteristik guru sebagai pendidik harus dapat menyesuaian dengan bahan ajar dan peserta didik. Guru harus memahami bagaimana peserta didik belajar dan mampu meningkatkan minat pada mata pelajaran dan meningkatkan motivasi belajar. Peserta didik juga belajar akhlak mulia melalui pengamatan terhadap prilaku guru ketika melaksanakan proses pembelajaran di kelas dan ketika di luar kelas di sekolah (Moh. Uzer Usman, 2010: 34).

Beberapa penelitian membuktikan bahwa guru yang profesional merupakan salah satu indikator penting dari sebuah lembaga pendidikan yang berkualitas, saatnyalah guru berupaya meningkatkan kualitas keprofesionalan diri. Diantara 
pengembangan profesi untuk menjadikan guru profesioanal adalah melalui Kelompok Kerja Guru Pendidikan Agama Islam (KKG PAI) Sekolah Dasar (SD).

Keberadaan organisasi profesi guru atau forum Kelompok Kerja Guru Pendidikan Agama Islam (KKG-PAI) Sekolah Dasar ini perlu diaktualisasikan dan diberdayakan sesuai perkembangan guna pembinaan dan pengembangan berbagai kompetensi guru Pendidikan Agama Islam (PAI) itu sendiri secara optimal, terpadu, faktual, dan berkelanjutan. Dalam ajaran Islam ada beberapa ayat al-Quran yang menganjurkan perihal musyawarah seperti yang tercantum di dalam surah Ali-'Imran: 159:
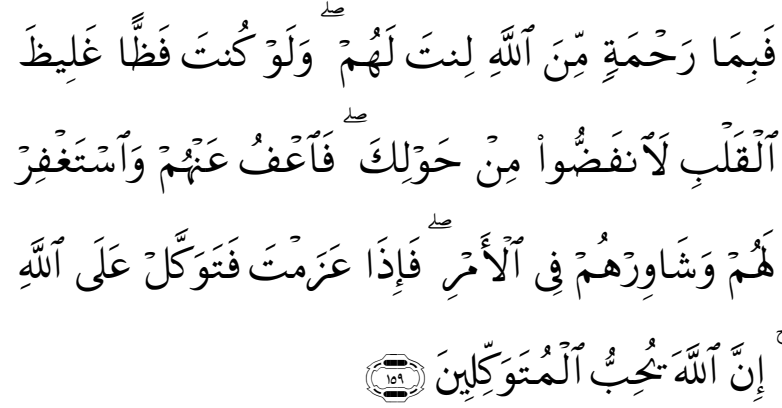

Artinya: Maka disebabkan rahmat dari Allah-lah kamu Berlaku lemah lembut terhadap mereka. Sekiranya kamu bersikap keras lagi berhati kasar, tentulah mereka menjauhkan diri dari sekelilingmu. karena itu ma'afkanlah mereka, mohonkanlah ampun bagi mereka, dan bermusyawaratlah dengan mereka dalam urusan itu kemudian apabila kamu telah membulatkan tekad, Maka bertawakkallah kepada Allah. Sesungguhnya Allah menyukai orang-orang yang bertawakkal kepada-Nya.

Mencermati makna kandungan ayat di atas tergambar sejumlah etika Islami dalam berinteraksi dan bersosialisasi, salah satunya adalah bermusyawarah. Melalui forum Kelompok Kerja Guru (KKG) diharapkan dapat mengadopsi nilai-nilai tersebut dan menumbuhkan kegairahan guru Pendidikan Agam Islam (PAI) untuk beraktualisasi meningkatkan keterampilan dan kemampuan dalam mempersiapkan, melaksanakan, dan mengevaluasi kegiatan pembelajaran yang inovatif. Semakin meningkatnya wawasan guru Pendidikan Agama Islam (PAI) diharapkan berimbas terhadap peningkatan kualitas peserta didik dan profesionalitas guru.

Kelompok kerja guru disingkat KKG adalah suatu wadah pembinaan profesional bagi para guru yang tergabung dalam organisasi gugus sekolah dalam rangka peningkatan mutu pendidikan. Seperti yang tercantum dalam UndangUndang Nomor 2 Tahun 1989 tentang Sistem Pendidikan Nasional pasal 31 ayat (4) yang berbunyi : "Setiap tenaga kependidikan berkewajiban untuk meningkatkan kemampuan profesional sesuai dengan tuntutan perkembangan ilmu pengetahuan dan tekhnologi serta pembangunan bangsa."

Melalui wadah KKG inilah guru dalam suatu gugus sekolah berkumpul, berdiskusi membicarakan hal yang berkaitan dengan tugas mengajar/ mendidik. KKG mengadakan pertemuan berkala yang berfungsi untuk meningkatkan mutu kegiatan belajar mengajar.

Adapun beberapa hal pokok yang melatar belakangi pentingnya kegiatan KKG PAI Kenyataan dilapangan menunjukkan bahwa guru Pendidikan Agama Islam kualifikasi keguruannya sangat beraneka ragam sehingga penampilannya dalam melaksanakan kegiatan belajar mengajar (KBM) sangat bervariasi. Pengaturan bagi angka kredit jabatan fungsional guru Pendidikan Agama Islam menuntut kemampuan guru Pendidikan Agama Islam untuk lebih meningkatkan profesioanlisme berkarya dan berprestasi di dalam melaksanakan tugas sehari-sehari di sekolah. Kenyataan bahwa hasil-hasil penataran guru Pendidikan Agama Islam yang dilaksanakan selama ini perlu ditunjang oleh kegiatan yang dilaksanakan dalam KKG PAI terutama dalam hal KBM/ 
pengelolaan kelas. Peningkatan kemampuan profesioanal guru Pendidikan Agama Islam menuntut adanya wadah, antara lain untuk komunikasi, informasi, diskusi dan pembinaan sesama guru Pendidikan Agam Islam. (http://karya ilmiah: Pedoman Pelaksanaan Kelompok Kerja Guru Pendidikan Agama Islam (KKG PAI) Pada Sekolah Dasar ).

\section{Peningkatan}

kemampuan profesionalisme seorang guru dapat ditempuh melalui dua jalur, yaitu jalur mandiri dan jalur resmi yang terkoordinasi. Jalur mandiri adalah berbentuk keaktifan seorang guru dalam kegiatan ilmiah yang dapat meningkatkan pengetahuan dan keprofesionalan guru. Sedangkan yang dimaksudkan dengan jalur resmi dan terkoordinasi adalah segala kegiatan yang sengaja diprogramkan untuk meningkatkan kemampuan profesional guru seperti berbentuk pelatihan-pelatihan, penataran, workshop, diskusi, temu ilmiah, dan lainlainnya.

Pada hakikatnya semua guru di sekolah dasar harus menjadikan guru yang profesionalisme. Pentingnya peningkatan kemampuan profesional guru di Sekolah Dasar dapat ditinjau dari beberapa sudut pandang, ditinjau dari perkembangan ilmu pengetahuan dan tekhnologi pendidikan, kepuasan dan moral kerja, keselamatan kerja guru, dan peranannya yang demikian penting dalam rangka implementasi manajemen peningkatan mutu berbasis sekolah di Sekolah Dasar (Ibrahim Bafadal, 2006: 62).

Keberadaan guru Pendidikan Agama Islam (PAI) Sekolah Dasar (SD) menuntut gurunya untuk menjadi guru yang profesionalisme, disamping itu perubahan kurikulum yang menuntut guru lebih meningkatkan mutu dirinya/ kompetensinya sehingga tugas dan kewajiban dapat dilaksanakan secara maksimal. Problem di kelas maupun di sekolah tempat tugasnya yang dihadapi, bervariasinya watak dan peserta didik serta tuntutan Undang-Undang Guru dan Dosen agar guru profesional.

Kelompok Kerja ini berfungsi sebagai wadah peningkatan mutu profesionalisme guru dan tenaga kependidikan. keberadaan pusat kegiatan guru (PKG) dalam sistem pembinaan profesionalme, secara organisatoris telah ada dan berfungsi. Namun terkadang, sistem pelaksanaannya kurang efektif sehingga tujuan yang diharapkan tidak dapat tercapai secara optimal.

melihat adanya masalah dalam diri guru, karena terjadi kesenjangan antara harapan dan kenyataan. Pemerintah telah memberikan kesejahteraan kepada guru melalui tunjangan profesi dan tunjangantunjangan lain sebagai harapan guru, tetapi mengapa realitasnya kinerja guru sampai sekarang masih rendah? Apa yang menyebabkan kinerja guru masih rendah?. Bagaimana mutu pendidikan kita kalau para pendidiknya dalam bertugas kinerjanya pas-pasan kalau tidak mau dikatakan rendah?

Berbagai upaya telah dilaksanakan oleh pemerintah antara lain dalam rangka peningkatan mutu dan profesionalisme guru PAI yang muaranya adalah peningkatan mutu pembelajaran di kelas, upaya tersebut antara lain ikut serta dalam pendidikan dan pelatihan. Namun pada kenyataannya implementasi di lapangan belum sepenuhnya dilaksanakan dengan sebaik-baiknya, indikasinya antara lain masih banyaknya guru yang belum mengaplikasikan ilmu yang diperolehnya, bahkan lebih parah lagi masih ada guru yang tidak faham tentang bagaimana cara pengaplikasian ilmu yang diperolehnya dari pendidikan dan latihan yang diikutinya.

$\begin{array}{lll}\text { MAKNA } & \text { DARI } & \text { PENINGKATAN } \\ \text { PROFESIONALISME } & \\ \text { Dalam } & \text { Kamus } & \text { Besar Bahasa } \\ \text { Indonesia, istilah } & \text { profesionalisme } \\ \text { ditemukan sebagai berikut: Profesi adalah }\end{array}$


bidang pekerjaan yang dilandasi pendidikan keahlian (keterampilan, kejuruan dan sebagianya) tertentu. Profesional adalah yang bersangkutan dengan profesi, memerlukan kepandaian khusus untuk menjalankannya dan mengharuskan adanya pembayaran untuk melakukannya. Kata "profesional" berasal dari kata sifat yang berarti pecaharian dan sebagai kata benda yang berarti orang yang mempunyai keahlian seperti guru, dokter, hakim dan sebagainya (Moh. Uzer Usman, 2010: 15).

Secara etimologi profesi dari kata profesion yang berarti pekerjaan. Profesional artinya orang yang ahli. Profesionalisme artinya sifat. Sudarmawan mendefinisikan secara terminologi, profesi dapat diartikan sebagai suatu pekerjaan yang mempersyaratkan pendidikan tinggi bagi pelakunya yang ditekankan pada pekerjaan mental, bukan pekerjaan manual. Kemampuan mental yang dimaksud di sini adalah adanya persyaratan pengetahuan teoritis sebagai instrumen untuk melakukannya perbuatan praktis (Sudarwan Danim, 2002: 21).

Profesionalisme yang berdasarkan keterbukaan dan kebijakan terhadap ideide pembaharuan itulah yang akan mampu melestarikan eksistensi madrasah atau sekolah kita, sebagaimana dalam hadits nabi Muhammad SAW bersabda:

"Jika suatu urusan diserahkan kepada orang yang bukan profesinya (ahlinya) maka tunggulah kehancurannya." (H.R. Bukhari).

Juga firman Allah swt yang mengingatkan kita semua seperti yang tercantum dalam surat Al-An'am ayat 135 adalah :

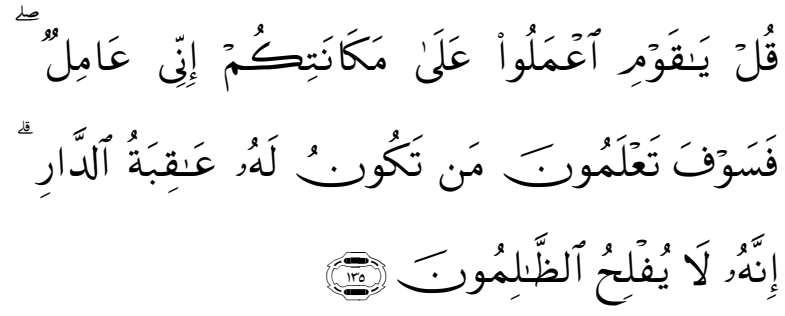

Artinya: Katakanlah "Hai kaumku, berbuatlah (bekerjalah) sepenuh kemampuanmu (menurut profesimu masing-masing, Sesungguhnya akupun berbuat (bekerja pula). kelak kamu akan mengetahui, siapakah (diantara kita) yang akan memperoleh hasil yang baik di dunia ini. Sesungguhnya orang-orang yang zalim itu tidak akan mendapatkan keberuntungan.

Terdapat banyak Pengertian Profesionalisme Guru menurut para ahli.

a. Ahmad Tafsir mendefinisikan bahwa profesionalisme adalah paham yang mengajarkan bahwa setiap pekerjaan harus dilakukan oleh orang yang profesional. Istilah profesional aslinya adalah kata sifat dari kata "profession" (pekerjaan) yang berarti sangat mampu melakukan pekerjaan.

b. Muhibbin menyatakan bahwa profesional merupakan suatu pekerjaan yang mampu diselesaikan dengan baik. Profesional berabri melakukan suatu hal berdasarkan kemapuan yang dimiliki untuk mata pencahariannya.

c. Kunandar menyatakan profesionalisme berasal dari kata profesi yang artinya suatu bidang pekerjaan yang ingin atau akan ditekuni oleh seseorang ( Kunandar, 2011: 45).

Jadi dapat ditarik kesimpulan bahwa profesi Pengertian guru profesionalme adalah orang yang memiliki kemampuan dan keahlian khusus dalam bidang keguruan sehingga ia mampu melakukan tugas dan fungsinya sebagai guru dengan maksimal (Moh. Uzer Usman, 2010: 15).

\section{SYARAT-SYARAT MENJADI GURU PROFESIONAL}

Dilihat dari tugas dan tanggung jawabnya, tenaga kependidikan ternyata bahwa untuk menyandang pekerjaan dan jabatan tersebut dituntut beberapa persyaratan. Menurut Muhammad Ali sebagai berikut:

a. Menuntut adanya keteramplilan yang 
berdasarkan konsep clan teori ilmu pengetahuan yang mendalam.

b. Menekankan pada suatu keahlian dalam bidang tertentu sesuai dengan bidang profesinya.

c. Menuntut tingkat pendidikan keguruan yang memadai.

d. Adanya kepekaan terhadap dampak kemasyarakatan dari pekerjaan yang dilaksanakannya.

Memungkinkan perkembangan sejalan dengan dinamika kehidupannya. Untuk itulah seorang guru harus mempersiapkan diri sebaik-baiknya untuk memenuhi panggilan tugasnya, baik berupa im-service training (diklat/ penataran) maupun pre service training (pendidikan keguruan secara formal) Secara khusus, sebagai sebuah profesi keguruan, ada beberapa kriteria seorang guru.

Menurut Muhammad Ali yang dikutip oleh Moh. Uzer Usman bahwa persyaratan profesi memerlukan persyaratan khusus yaitu:

1. Menuntut adanya keterampilan yang berdasarkan konsep dan teori ilmu pengetahuan yang mendalam.

2. Menekankan pada suatu keahlian dalam bidang tertentu sesui dengan bidang profesinya.

3. Menuntut adanya tingkat pendidikan keguruan yang memadai.

4. Adanya kepekaan terhadap dampak kemasyarakatan dari pekerjaan yang dilaksanakannya.

5. Memungkinkan perkembangan sejalan dengan dinamika kehidupan. (Moh. Uzer Usman, 2011: 15). Secara khusus syarat profesionalisme guru dalam Islam adalah:

1. Sehat jasmani dan rohani

2. Bertakwa

3. Berilmu pengetahuan yang luas

4. Berlaku adil

5. Berwibawa

6. Ikhlas

7. Mempunyai tujuan yang rabbani

8. Mampu merencanakan dan melaksanakan evaluasi (Http:

Hidayati Ramli. blogspot. Com /2016/11/ peningkatan- profesionalguru- melalui-kkg. Karya ilmiah Program Peningkatan Kualifikasi Guru Madrasah dan Guru Pendidikan Agama Islam pada Sekolah, Etika Profesi, (Jakarta: Depertemen Agama, 2009.html).

Dalam Islam seorang guru yang baik tidak hanya cerdas tapi juga harus berpengetahuan serta harus bertaqwa dan berakhlak baik, ikhlas menjalankan tugas sebagai pendidik karena Allah, sehingga dari sebuah tujuan yang mulia tersebut lahir penerus dunia pendidikan yang mampu menghadapi berbagai tantangan pendidikan, karena guru yang baik tidak hanya menjadi pendidik yang bertaqwa tapi menjadi teladan seperti Rasulullah Saw yang mampu menyelamatkan umat dari lembah yang gelap gulita (Http: Hidayati Ramli. blogspot. Com /2016/11/ peningkatan- profesional- guru- melalui$k k g$. Karya ilmiah Program Peningkatan Kualifikasi Guru Madrasah dan Guru Pendidikan Agama Islam pada Sekolah, Etika Profesi, Jakarta: Depertemen Agama, 2009. html ).

\section{URGENSI PROFESIONALISME}

Pada dasarnya profesionalisme dan sikap profesional itu merupakan motivasi intrinsik yang ada pada diri seseorang sebagai pendorong untuk mengembangkan dirinya menjadi tenaga profesional. Motivasi intrinsik tersebut akan berdampak pada munculnya etos kerja yang unggu (exellence) yang ditunjukkan dalam lima bentuk kerja sebagai berikut:

a. Keinginan untuk selalu menampilkan perilaku yang mendekati standar ideal. Berdasarkan kreteria ini, jels bahwa guru yang memiliki profesionl tinggi akan selalu berusaha mewujudkan dirinya sesuai dengan standar ideal akan mengidentifikasikan dirinya kepada figur yang dipandang memiliki 
standar ideal.

b. Meningkatkan dan memelihara citra profesi. Profesionalisme yang tinggi ditunjukkan oleh besarnya keinginan untuk selalu meningkatkan dan memelihara citra profesi melalui perwujudan dilakukan melalui berbagi cara, penampilan, cara bicara, penggunaan bahasa, postur, sikap hidup sehari-hari, hubungan antarpribadi, dan sebaginya (Ali Mudlofir, 2012: 32-34).

c. Memanfatkan setiap kesempatan pengembangan profesional. Berdasarkan kreteria ini, para guru diharapkan selalu berusaha mencari dan memanfaatkan kesempatan yang dapat mengembangkan profesinya. Berbagai kesempatan yang dpat dimanfaatkan antra lain: mengikuti kegiatan ilmiah seperti loka karya, seminar, mengikuti penataran atau pendidikan lanjutan, melakukan penelitian dan pengabdian pada masyarakat, menelaah kepustakaan, membuat karya ilmiah, serta memasuki organisasi profesi (Ali Mudlofir, 2012: 32-34).

d. Mengejar kualitas dan cita-cita dalam profesi. Hal ini mengandung makna bahwa profesionalisme yang tinggi ditunjukkan dengan adanya upaya untuk selalu mencapai kualitas dan cita-cita sesuai dengan program yang telah ditetapkan. Guru memiliki profesionalisme tinggi akan selalu aktif dalam seluruh kegiatan dan perilakunya untuk menghasillkan kualitas yang ideal.

e. Memiliki kebanggaan terhadap profesinya. Profesionalisme ditandai dngan kualitas derajat kebanggaan akan profesi yng dipegangnya. Dalam kaitan ini, diharapkan agar para guru memiliki rasa bangga dan percaya diri akan profesinya. Rasa bangga ini ditunjukkan dengan penghargaan akan pengalaman di masa lalu, berdedikasi tinggi terhadap tugas-tugasnya sekarang, dan meyakini akan potensi dirinya bagi perkembangan di masa depan (Ali Mudlofir, 2012: 32-34).

\section{PENGERTIAN GURU PAI}

Dalam kamus besar Bahasa Indonesia (KBBI), kata guru/gu/ru/ orang yang pekerjaannya (mata pencahariannya, profesinya) mengajar. Guru sebagai pendidik dalam konteks pendidikan Islam disebut dengan murabbi, mu'alim dan muaddib. Kata murabi berasal dari kata rabba-yurabbi. Kata mualim isim fail dari allama-yuallimu sebagaimana ditemukan dalam Al-Qur'an (QS. Al-Baqarah ayat 31).

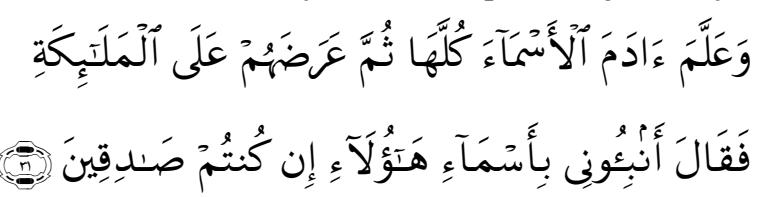

Artinya: Dan Dia mengajarkan kepada Adam Nama-nama (benda-benda) seluruhnya, kemudian mengemukakannya kepada Para Malaikat lalu berfirman: "Sebutkanlah kepada-Ku nama bendabenda itu jika kamu mamang benar orangorang yang benar.

1. Menurut Pendapat Syarifuddin Nurdin dan Usman, sebagaimana yang dikutip oleh Akmal Hawi, Guru adalah: "Seseorang yang bukan hanya sekedar memberi ilmu pengetahuan kepada murid-muridnya, akan tetapi ia seorang tenaga professional yang dapat menjadikan murid-muridnya mampu merencanakan, menganalisa, dan menyimpulkan masalah yang dihadapi".

2. Menurut Purwanto guru adalah orang yang diserahi tanggung jawab sebagai pendidik di dalam lingkungan sekolah adalah guru.

3. Menurut Surya guru sebagai pendidik profesional selayaknya mempunyai citra baik di masyarakat, guru itu ditiru atau diturut dan di contoh.

4. Menurut Zakiyah Daradjat guru PAI ialah pendidikan yang dilaksanakan 
berdasarkan Islam (Zakiyah Daradjat, 2008: 86).

Dari pengertian ini dapat disimpulkan bahwa Pengertian upaya guru adalah usaha yang harus dilakukan oleh guru agar siswa itu menjadi pribadi yang disiplin. guru dalam melaksanakan pendidikan baik di lingkungan formal maupun non formal dituntut untuk mendidik dan mengajar. Karena keduanya mempunyai peranan yang penting dalam proses belajar mengajar untuk mencapai tujuan ideal pendidikan.

Dengan demikian guru itu juga diartikan di gugu dan ditiru, guru adalah orang yang dapat memberikan respon positif bagi peserta didik dalam proses belajar mengajar, untuk sekarang ini sangatlah diperlukan guru yang mempunyai basic yaitu (kompetensi) sehingga proses belajar mengajar yang berlangsung berjalan sesuai dengan yang kita harapkan (Oemar Hamalik, 2004: 116).

\section{SYARAT-SYARAT GURU}

Dalam perspektif pendidikan islam, keberadaan, peranan dan fungsi guru merupakan keharusan yang tak bisa diingkari. Tidak ada pendidikan tanpa "kehadiran" guru. Guru merupakan penentuan arah dan sistematika pembelajaran mulai dari kurikulum, sarana, bentuk-pola, sampai kepada usaha bagaimana anak didik seharusnya belajar dengan baik dan benar dalam rangka mengakses diri akan pengetahuan dan nilai-nilai hidup. Guru merupakan yang berperan sebagai pemberi petunjuk kearah anak didik yang lebih baik" (Iman Tholhah dan Ahmad Barizi, 2004: 219).

Dalam lembaga pendidikan formal guru merupakan faktor pendidikan yang memiliki peran penting dalam menentukan aktifitas pembelajaran, guru adalah merupakan petugas lapangan dalam pendidikan yang selalu bergaul secara langsung dengan murid sebagai obyek pokok dalam pendidikan karena itu seorang guru harus memenuhi berbagai persyaratan.

Di dalam pasal 42 UU RI No. 20 tahun 2003 tentang sistem pendidikan nasional menyatakan tentang syaratsyarat guru sebagai berikut:

a. Pendidik harus memiliki kualifikasi minimum dan sertifikasi sesuai dengan jenjang kewenangan mengajar, sehat jasmani dan rohani serta memiliki kemampuan untuk mewujudkan tujuan pendidikan nasional.

b. Pendidik untuk pendidikan formal pada jenjang pendidikan usia dini, pendidikan dasar, pendidikan menengah dan pendidikan tinggi dihasilkan oleh perguruan tinggi yang terakreditasi.

Ketentuan mengenai kualifikasi pendidikan sebagaimana dimaksud dalam ayat 1 dan 2 diatur lebih lanjut dengan pemerintah (UU RI No. 20 Tahun 2003 tentang Sistem Pendidikan : 72 ).

Pekerjaan guru adalah pekerjaan profesional, maka untuk menjadi guru itu harus memiliki persyaratan sebagai berikut :

a. Harus memiliki bakat sebagai guru.

b. Harus memiliki keahlian sebagai guru.

c. Memiliki kepribadian yang baik dan terintegrasi.

d. Memiliki mental yang sehat.

e. Berbadan sehat.

f. Memiliki pengalaman dan pengetahuan luas.

g. Guru adalah manusia yang berjiwa Pancasila.

h. Guru adalah seorang warga negara yang baik (Oemar Hamalik, 2007: 118).

Guru harus berlakuan baik, jika kita mengatakan "berkelakuan baik", maka didalamnya terkandung segala sikap, watak dan sifat-sifat yang baik antara lain:

a. Calon sungguh berbakat

b. Pandai bahasa sopan

c. Kepribadiannya harus baik dan kuat

d. Harus disenangi dan disegani oleh anak didik 
e. Emosinya harus stabil

f. Pandai menyesuaikan diri

g. Tidak boleh sensitive

h. Harus tenang, obyektif dan bijaksana

i. Harus jujur dan adil

j. Harus susila di dalam tingkah lakunya

k. Sifat sosialnya harus besar (Hasbullah, 2013: 121\}

Pendapat lain mengatakan bahwa syarat-syarat yang harus dipenuhi seorang guru sebagai suatu profesi. Seorang guru harus memenuhi kriteria profesional sebagai berikut :

a. Fisik

1. Sehat jasmani dan rohani.

2. Tidak mempunyai cacat tubuh yang bisa menimbulkan ejekan atau cemoohan atau rasa kasihan dari anak didik.

b. Mental dan Kepribadian.

1. Mencintai bangsa dan sesama manusia dan rasa kasih sayang kepada anak didik.

2. Berbudi pekerti luhur.

3. Berjiwa kreatif, dapat memanfaatkan rasa pendidikan yang ada secara maksimal.

4. Bersifat terbuka, peka dan inovatif.

5. Mampu mengembangkan kecerdasan yang tinggi.

c. Keilmuan atau Pengetahuan dan Keterampilan

1. Memahami ilmu pendidikan dan keguruan dan mampu menerapkan-nya dalam tugasnya sebagai pendidik.

2. Memahami, menguasai serta mencintai ilmu pengetahuan yang akan diajarkan.

3. Mampu memecahkan persoalan secara sistematis terutama yang berhubungan dengan bidang studi serta memahami prinsip-prinsip kegiatan belajar mengajar" (Oemar Hamalik, 2004: 38).

\section{TANGGUNG JAWAB GURU}

Kalau kita melihat pada perubahanperubahan transisional dalam pengajaran seperti yang telah diuraikan dalam bagian terdahulu yang menambah kesempatan bagi murid-murid untuk belajar dan berkembang, dan dilain pihak berdasarkan peranan profesional guru modern maka sudah barang tentu menambah tanggung jawab guru menjadi lebih besar. Tanggung jawab itu adalah sebagai berikut:

1. Guru Harus Menuntut Murid-Murid Belajar

Tanggung jawab guru yang tepenting ialah merencanakan dan mengajak murid-murid untuk melakukan kegiatan belajar guna mencapai pertumbuhan dan perkembangan yang diinginkan. Guru harus membimbing murid agar mereka memperoleh keterampilan- keterampilan, pemahaman, perkembangan sebagai kemampuan, kebiasaan-kebiasaan yang baik, dan perkembangan sikap serasi.

2. Turut Serta Membina Kurikulum Sekolah

Sesungguhnya guru merupakan seorang key person yang paling mengetahui tentang kebutuhsn kurikulum yang sesuai dengan tingkat perkembangan murid. Karena itu sewajarnya apabila dia turut aktif dalam pembinaan kurikulum disekolah (Oemar Harnalik, 2007: 127-128).

3. Melakukan Pembinaan Terhadap Diri Siswa (Kepribadian, Watak Dan Jasmani)

Memompakan pengetahuan kepada murid kiranya bukan pekerjaan yang sulit. Tetapi membina siswa agar menjadi manusia berwatak (berkarakter) sudah pasti bukan pekrejaan yang mudah. Mengembangkan watak dan kepribadiaannya, sehingga mereka memiliki kebiasaan, sikap, cita-cita, berpikir dan berbuat, berani bertanggung jawab, ramah dan mau bekerja sama.

4. Memberikan Bimbingan Kepada Murid bimbingan kepada murid agar mereka mampu mengenal dirinya sendiri, memecahkan masalahnya sendiri, mampu menghadapi kenyatatn dan 
memeliki stamina emosional yang baik, sangat diperlukan. Mereka perlu dibimbing ke arah terciptanya hubungan pribadi yang baik dengan temannya dimana perbuatan dan perkataan guru dapat dicontoh yang hidup.

5. Melakukan Diagnosis Atas KesulitanKesulitan Belajar Dan Mengadakan Penilaian Atas Kemajuan Belajar.

Guru bertanggung jawab menyesuaikan semua situasi belajar dengan minat, latar belakang, dan kematangan siswa.

6. Menyelenggarakan Penelitian

Sebagai seorang yang bergerak dalam bidang keilmuan (scientist) bidang pendidikan maka ia harus senantiasa memperbaiki cara bekerjanya. Tidak cukup sekedar melaksanakan pekerjaan rutin saja, melainkan harus juga berusaha menghimpun banyak data melalui penelitian yang kontinu dan intensif (Oemar Harnalik, 2007: 129-130).

7. Mengenal Masyarakat dan Ikut Serta Aktif

Guru tak mungkin melaksanakan pekerjaaannya secara efektif, jikalau ia tidak mengenal masyarakat seutuhnya secara lengkap. Harus dipahami dengan baik tentang pola kehidupan, kebudayaan, minat dan kebutuhan masyarakat, karena perkembangan sikap, minat, aspirasi anak sangat banyak dipengaruhi oleh masyarakat sekitarnya.

8. Menghayati, Mengamalkam dan Mengamankan Pancasila

Pancasila merupakan pandangan hidup bangsa yang mendasari semua sendisendi hidup dan kehidupan nasional, baik individua maupun masyarakat kecilsampai dengan kelompok sosial yang terbesar termasuk sekolah. Pendidikan bertujuan membentuk manusia pancasila sejati, yang berarti melalui pendidikan diantaranya di sekolah, kita berusaha semaksimal mungkin agar tujuan itu tercapai.
9. Turut Serta Membantu Terciptanya Kesatuan dan Persatuan Bangsa dan Perdamaian Dunia

Guru bertanggung jawab untuk mempersiapkan siswa menjadi warga negara yang baik. Pengertian yang baik ialah antara lain memiliki rasa persatuan dan kesatuan sebagai bangsa. Perasaan demikian dapat tercipta apabila para siswa didik saling menghargai, mengenal daerah, masyarakat, adat istiadat, seni budaya, sikap, hubungan-hubungan sosial, keyakinan, kepercayaan, , peninggalanpeninggalan historis setempat, keinginan, dan minat dari daerahdaerah lainnya di seluruh nusantara (Oemar Harnalik, 2007: 130-131).

\section{PERANAN SOSIAL GURU DI SEKOLAH}

a. Guru sebagai pengelola kelas

Dalam perannya sebagai pengelola kelas (learning manager) guru hendaknya mampu mengelola kelas sebagai lingkungan belajar serta merupakan aspek dari lingkungan sekolah yang perlu diorganisasikan . Lingkungan ini diatur dan diawasi agar kegiatan-kegiatan belajar terarah kepada tujuan-tujuan pendidikan. Lingkungan yang baik ialah yang bersifat menantang dan merangsang siswa untuk belajar, memberikan rasa aman dan kepuasan dalam mencapai tujuan.

b. Guru sebagai Evaluator

Guru hendaknya terus menerus mengikuti hasil belajar yang telah dicapai oleh siswa dari waktu kewaktu. Informasi yang diperoleh melalui evaluasi atau penilaian merupakan umpan batik (feed back) terhadap belajar mengajar. Umpan balik ini akan dijadikan titik tolak untuk memperbaiki dan meningkatkan proses belajar mengajar akan terusmenerus ditingkatkan untuk memperoleh hasil yang optimal.

c. Guru sebagai pengelola pembelajaran 
Guru juga berperan dalam membimbing pengalaman sehari-hari kearah pengenalan tingkah laku dan kepribadiannya sendiri. Salah satu ciri manejemen kelas yang baik adalah tersedianya kesempatan bagi siswa untuk sedikit demi sedikit mengurangi ketergantunganya pada guru hingga mereka mampu membimbing kegiatannya. sendiri.

Sebagai manejer, guru hendaknya mampu mempergunakan pengetahuan tentang teori belajar mengajar dari teori perkembangan hingga memungkinkan untuk menciptakan situasi belajar yang baik mengendalikan pelaksanaan pengajaran dan pencapaian tujuan.

d. Guru sebagai pekerja social

Petugas sosial yaitu seorang yang harus membantu untuk kepentingan masyarakat. Dalam kegiatan-kegiatan masyarakat guru senantiasa merupakan petugas-petugas yang dapat dipercaya untuk berpartisipasi didalamnya (Ahmadi H. Syukran Nafis, 2010: 47-48).

e. Guru sebagai Ilmuan

Guru senantiasa terus menerus menuntut ilmu pengetahuan. Dengan berbagai cara, setiap guru senantiasa belajar untuk mengikuti perkembangan ilmu pengetahuan agar dapat mengikuti perkembangan zaman.

f. Guru sebagai Orang Tua dan Teladan Guru mewakili orang tua murid di sekolah dalam pendidikan anaknya. Sekolah merupakan lembaga pendididikan sesudah keluarga, sehingga dalam arti luas sekolah merupakan keluarga, guru berperan sebagai orang tua bagi siswa siswinya. Oleh karena itu guru perlu berusaha sekuat tenaga agar dapat menjadi teladan yang baik untuk siswa bahkan untuk seluruh masyarakat.

g. Guru sebagai penacari keamanan Guru perlu senantiasa mencariakan rasa aman bagi siswa. Guru menjadi tempat berlindung bagi siswa-siswa untuk memperoleh rasa aman dan puas didalamnya.

h. Guru sebagai psikolog dalam pendidikan

Peran guru sebagai psikolog, guru dipandang sebagai petugas psikolog dalam pendidikan yang melaksanakan tugasnya atas dasar prisipprinsip psikolog. (I Wayan Suwatra, 2014: 3435).

\section{PENGERTIAN KKG PAI}

Kelompok kerja guru pendidikan Agama Islam disingkat KKG PAI adalah wadah kegiatan profesional untuk meningkatkan pengetahuan dan kemampuan serta untuk membina hubungan kerjasama secara koordinatif dan fungsional antara sesama Guru Pendidikan Agama Islam yang bertugas pada Sekolah Dasar dan tergabung dalam organisasi gugus sekolah dengan memanfaatkan potensi atau kemampuan yang ada pada masing-masing guru (Http: Sayyidridlo 27.blogspot. com/2016/06/ Karya ilmiah: Pedoman Pelaksanaan Kelompok Kerja Guru Pendidikan Agama Islam (KKG PAI) Pada Sekolah Dasar. Departemen Agama Jawa Timur.blogspot.com). Berikut beberapa pendapat ahli tentang KKG guru PAI:

a. Trimo Kelompok Kerja Guru yaitu suatu organisasi profesi guru yang bersifat struktural yang dibentuk oleh guru-guru di suatu wilayah atau gugus sekolah sebagai wahana untuk saling bertukaran pengalaman guna meningkatkan kemampuan guru dan memperbaiki kualitas pembelajaran.

b. Sedangkan Sumadji menyatakan, "kelompok kerja guru ini merupakan wadah atau tempat bagi guru untuk bermusyawarah tentang hal-hal untuk peningkatan mutu dalam pembelajaran".

c. Pendapat lain dikatakan oleh Uceh Nurabnu, Kelompok Kerja Guru (KKG) "merupakan salah satu bagian dari 
program kerja gugus sebagai wahana bengkel kerja guru-guru SD selaku anggota gugus, dan merupakan pintu masuk pertama yang paling strategis dalam program peningkatan kompetensi pendidik SD" (http: hucokhs. blogspot. com /2016/12/14/pengertian-dan-sejarah berdirinya-kkg.html).

Dari pengertian di atas dapat disimpulkan bahwa pengertian KKG PAI adalah merupakan wadah atau tempat bagi guru untuk bermusyawarah tentang hal-hal untuk peningkatan mutu dalam pembelajaran.

Ada banyak ragam kegiatan pengembangan dan pembinaan profesi guru baik di sekolah dasar, menengah maupun keatas misal KKG, MGMP, PGRI, dll. melalui pendekatan gugus sekolah dasar. Sedangkan pada tingkat Sekolah Dasar kegiatan tersebut bernama KKG. Ketua gugus sekolah dasar dapat memprogramkan penataran mini bagi guru dalam setiap libur catur wulan (Ibrahim Bafadal, 2006: 60).

Sebagai fasilitasnya bisa kepala SD inti, tutor, guru pemandu atau pengawas SD setempat. Selain itu di gugus sekolah dasar melalui KKG dapat menyelenggarakan pertemuan-pertemuan rutin, bisa satu kali dalam satu minggu, satu kali dalam dua minggu, atau satu kali dalam satu bulan. Pertemuan yang dimaksud adalah pertemuan antar guru dalam KKG. Melalui pertemuanpertemuan tersebut diharapkan dapat :

1. Menumbuh kembangkan rasa kebersamaan dan kekeluargaan diantara sekolah dasar anggota gugus dalam mencapai tujuan, dan mengusahakan berbagai upaya peningkatan pendidikan di sekolah dasar yang menjadi tanggung jawabnya.

2. Membudayakan berbagai kegiatan positif yang dapat menambah dan meningkatkan mutu profesionalisme guru yang menyangkut pengetahuan, ketrampilan, dan wawasan yang akan memberi dampak peningkatan mutu pendidikan dan hasil kegiatan belajarmengajar.

1. Membangun memecahkan masalah dan saling meringankan beban antar sekolah dasar anggota gugus.

2. Mencari informasi dan bahan dari berbagai sumber yang dapat dikembangkan bersama sebagai kreativitas dalam menciptakan inovasi pendidikan di dalam gugus sekolah dasar.

3. Memelihara komunikasi secara teratur antara sesama anggota gugus guna saling menyerap kiat-kiat keberhasilan pada setiap sekolah dasar anggota gugus atau sekolah dasar gugus lain.

4. Mengembangkan pola mekanisme pembinaan profesionalisme guru yang lebih efektif dan efisien.

5. Memacu guru dan kepala sekolah dasar untuk terus belajar meningkatkan mutu dan tanggap terhadap tugas profesi sebagai guru.

6. Mengembangkan hasil penataran pelatihan sesama teman sejawat dalam meningkatkan mutu profesi guru.

Pembentukan gugus sekolah dasar didasarkan kepada berbagai kebijaksanaan dan peraturan pemerintah diantaranya adalah peraturan No.28 Tahun 1990 tentang Pendidikan Dasar (Bafadal ibrahim, 2006: 59). Keputusan Menteri Pendidikan dan Kebudayaan RI Nomor 0487/U/1982 tentang Sekolah Dasar dan Keputusan Direktur Jenderal Pendidikan Dasar dan Menengah Nomor 079/C/K/I/1993 tentang pedoman pelaksanaan sistem pembinaan profesional guru melalui pembentukan gugus sekolah di Sekolah Dasar.

\section{FUNGSI DAN TUJUAN KEGIATAN KKG PAI}

Dalam pelaksanaan suatu kegiatan, pasti selalu memiliki fungsi dan tujuan tersendiri dalam pelaksanaan kegiatan tersebut. Adapun fungsi dan tujuan pelaksanaan kegiatan KKG PAI adalah 
sebagai berikut:

1. Fungsi KKG PAI

Kelompok Kerja Guru Pendidikan

Agama Islam SD berfungsi sebagai:

a. Forum komunikasi antar sesama Guru Pendidikan Agama Islam dalam peningkatan kemampuan profesional dan fungsional

b. Forum konsultasi yang berkaitan dengan kegiatan dan materi pembelajaran, metodologi, evaluasi dan sarana penunjang

c. Forum penyebarluasan informasi tentang segala kebijakan yang berkaitan dengan usaha-usaha pembaharuan dalam bidang pendidikan.

2. Tujuan KKG PAI

Kelompok Kerja Guru Pendidikan Agama Islam (KKG PAI) bertujuan untuk:

a. Meningkatkan rasa kebersamaan dan tanggung jawab sebagai pendidik agama islam yang bertujuan menanamkan keimanan (tauhid) dan ketaqwaan terhadap Allah SWT.

b. Menumbuhkan kegairahan Guru Pendidikan Agama Islam untuk meningkatkan kemampuan dan ketrampilan dalam mempersiapkan, melaksanakan dan mengevaluasi program Kegiatan Belajar Mengajar (KBM) Pendidikan Agama Islam (Http: Sayyidridlo 27.blogspot. com/2016/06/ Karya ilmiah: Pedoman Pelaksanaan Kelompok Kerja Guru Pendidikan Agama Islam (KKG PAI) Pada Sekolah Dasar. Departemen Agama Jawa Timur.blogspot.com).

c. Meningkatkan kemampuan dan kemahiran Guru Pendidikan Agama Islam dalam melaksanakan kegiatan belajar mengajar sehingga dapat menunjang usaha peningkatan pemerataan mutu Pendidikan Agama Islam.

d. Menampung segala permasalahan yang dialami oleh Guru Pendidikan Agama Islam dalam melaksanakan tugas sehari-hari dan bertukar pikiran serta mencari cara penyelaesaiannya sesuai dengan karakteristik pelajaran Pendidikan Agama Islam. Guru pendidikan agama islam sekolah dan lingkungan (Ibrahim Bafadal, 2006: 59).

e. Membantu Guru Pendidikan Agama Islam dalam upaya memenuhi kebutuhannya yang berkaitan dengan Kegiatan Belajar-Mengajar Pendidikan Agama Islam.

f. Membantu Guru Pendidikan Agama Islam memperoleh informasi teknis edukatif yang berkaitan dengan kegiatan Pendidikan Agama Islam. Kebijaksanaan kurikuler Pendidikan Agama Islam dan mata pelajaran lain yang bersangkutan.

g. Membantu Guru Pendidikan Agama Islam untuk bekerjasama dalam meningkatkan kegiatan-kegiatan intra dan ekstra kurikuler Pendidikan Agama Islam.

h. Memperluas wawasan dan saling tukar menukar informasi dan pengalaman dalam rangka mengikuti perkembangan ilmu pengetahuan dan tekhnologi serta pengembangan metode/tekhnik mengajar Pendidikan Agama Islam.

i. Meningkatkan

kemampuan profesionalisme berkarya dan berprestasi dalam pelaksanaan angka kredit bagi jabatan fungsional Guru Pendidikan Agama Islam.

Pembentukan gugus sekolah di Sekolah Dasar bertujuan untuk memperlancar upaya peningkatan profesioanalisme para guru Sekolah Dasar dan tenaga kependidikan lainnya dalam satu gugus (Ibrahim Bafadal, 2006: 59).

\section{PENINGKATAN PROFESIONALISME GURU PAI MELALUI KKG PAI}

\begin{tabular}{llr} 
Adapun bentuk & \multicolumn{2}{c}{ peningkatan } \\
profesionalisme guru & PAI & melalui \\
Kegiatan Kelompok & Kerja Guru \\
Pendidikan Agama Islam & (KKG PAI) ini \\
bersifat tentatif dengan bentuk kegiatan
\end{tabular} 
terdiri atas hal-hal yang pokok dan yang penting lainnya, sebagai berikut (Ibrahim Bafadal, 2006: 59):

1. Hal-hal yang pokok.

a. Kegiatan dalam bidang kurikulum pendidikan agama islam.

1) Pemahaman kurikulum.

2) Klasifikasi materi pendidikan agama Islam.

3) Penjabaran dalam topik-topik program cawu.

b. Kegiatan dalam bidang penyusunan mengajar.
1) Penyusunan rencana catur wulan.
2) Penyusunan rencana harian atau satuan pelajaran.

c. Pembahasan tentang metodologi pendidikan agama islam yang efektif dan efisien untuk masing-masing unsur pokok.
1) Keimanan.
2) Ibadah.
3) Akhlak.
4) Al Qur'an.
5) Muamalah.
6) Syariah.
7) Tarikh.

d. Pembahasan tentang alat dan media pembelajaran.

1) Jenis-jenis dan media yang perlu dipakai dalam pendidikan agama islam.

2) Penyediaan alat dan media.

3) Cara penggunaan alat dan media pendidikan agama islam.

e. Pembahasan tentang evaluasi pendidikan agama islam.
1) Sistem evaluasi.
2) Tekhnik evaluasi.
3) Cara menyusun soal.
4) Sistem scoring.
5) Tindak lanjut hasil evaluasi.

2. Hal - hal yang penting lainnya.

a. Pembahasan tentang pembuatan atau penyusunan Lembaran Kegiatan Siswa.

b. Pembahasan tentang permasalahan yang ditemui dalam proses belajar mengajar dan jalan keluarnya (Http: Sayyidridlo 27.blogspot. com/2016/06/ Karya ilmiah: Pedoman Pelaksanaan Kelompok Kerja Guru Pendidikan Agama Islam (KKG PAI) Pada Sekolah Dasar. Departemen Agama Jawa Timur.blogspot.com).

c. Pembahasan tentang pelaksanaan bimbingan dan penyuluhan agama di sekolah.

d. Pembahasan tentang buku pendidikan agama islam.

1. Buku teks pokok.

2. Buku teks pelengkap.

3. Buku pedoman guru.

4. Buku bacaan.

5. Buku sumber.

e. Pembahasan tentang problematika peserta didik.

f. Pembahasan tentang kasus-kasus khusus.

g. Pembahasan tentang kerjasama lintas sektoral.

h. Pembahasan tentang kerjasama lintas kelompok masyarakat.

i. Pembahasan tentang peraturan perundangan.

j. Pembahasan tentang buletin pendidikan.

k. Kegiatan studi perbandingan dalam bidang pendidikan.

l. Kegiatan karyawisata.

m. Pembahasan tentang angka kredit.

a. Pemahaman peraturan tentang angka kredit.

b. Pembahasan usaha dan bentukbentuk kegiatan yang perlu diciptakan dalam rangka memperoleh angka kredit.

c. Pembahasan tentang prosedur memperoleh angka kredit.

Pembahasan tentang persyaratan usulan kenaikan pangkat (Ibrahim Bafadal, 2006: 59).

\section{PENUTUP}

Berdasarkan uraian di atas dapat disimpulkan bahwa: pertama, 
Peningkatan kemampuan profesioanal guru Pendidikan Agama Islam menuntut adanya wadah, antara lain untuk komunikasi, informasi, diskusi dan pembinaan sesama guru Pendidikan Agam Islam.

Kedua, Peningkatan kemampuan Guru KKG sebagai guru profesional adalah guru yang menguasai karakteristik bahan ajar dan karakteristik pesreta didik. Karakteristik bahan ajar meliputi konsep, prinsip, teori yang terdapat dalam bahan ajar. Karakteristik peserta didik meliputi potensi, sikap, minat, akhlak mulia, dan personaliti peserta didik. Penguasaan karakteristik bahan ajar dan peserta didik diperlukan untuk menentukan metode dan strategi pembelajaran. Selain itu karakteristik guru sebagai pendidik harus dapat menyesuaian dengan bahan ajar dan peserta didik. Guru harus memahami bagaimana peserta didik belajar dan mampu meningkatkan minat pada mata pelajaran dan meningkatkan motivasi belajar. Peserta didik juga belajar akhlak mulia melalui pengamatan terhadap prilaku guru ketika melaksanakan proses pembelajaran di kelas dan ketika di luar kelas di sekolah.

Ketiga, Kelompok Kerja Guru Pendidikan Agama Islam (KKG PAI) bertujuan untuk Meningkatkan rasa kebersamaan dan tanggung jawab sebagai pendidik agama islam yang bertujuan menanamkan keimanan (tauhid) dan ketaqwaan terhadap Allah SWT. Menumbuhkan kegairahan Guru Pendidikan Agama Islam untuk meningkatkan kemampuan dan keterampilan dalam mempersiapkan, melaksanakan dan mengevaluasi program Kegiatan Belajar Mengajar (KBM) Pendidikan Agama Islam.[] 


\section{DAFTAR RUJUKAN}

Arikunto, Suharsimi. Prosedur Penelitian Suatu Pendekatan Praktis. Jakarta: Rineka Cipta. 1993.

Bafadal, Ibrahim. Peningkatan Profesionalisme Guru Sekolah Dasar. Jakarta: Bumi Aksara, 2006.

Dairi, Rizal. Metodologi Penelitian. Pekanbaru: UIR Pres. 2008.

Danim, Sudarwan. Inovasi Pendidikan, Bandung: Pustaka Setia, 2002.

Daradjat, Zakiah. Ilmu Pendidikan Islam, Jakarta: Bumi Aksara, 2008.

E. Mulyasa, Menjadi Guru Profesional, Jakarta: Remaja Rosdakarya, 2006.

Faisah, Hasnah. Menulis Karangan Ilmiah, Pekanbaru: Cendikia Insani, 2011.

Harnalik, Oemar. Proses Belajar Mengajar, Jakarta: Bumi Aksara, 2007.

Http: Hidayatiramli. blogspot. Com /2016/11/ peningkatanprofesional- guru- melalui-kkg. Karya ilmiah Program Peningkatan Kualifikasi Guru Madrasah dan Guru Pendidikan Agama Islam pada Sekolah, Etika Profesi, Jakarta: Depertemen Agama, 2009. html

Http: Hucokhs. Blog. spot. com /2016/12/14/pengertian-dansejarah berdirinya-kkg.html).

Http: Sayyidridlo 27.blogspot. com/2016/06/ Karya ilmiah: Pedoman Pelaksanaan Kelompok Kerja Guru Pendidikan Agama Islam (KKG PAI) Pada Sekolah Dasar. Departemen Agama Jawa Timur.blogspot.com.

Ihsan, Fuad. Dasar-Dasar Kependidikan, Jakarta: Rineka Cipta, 2005.

Kunandar, Guru Profesional Implementasi Kurikulum Tingkat Satuan Pendidikan

(KTSP) dan Sukses dalam Sertifikasi Guru, Jakarta: Rajawali Press, 2009.

Mudlofir, Ali. Pendidik Profesional, Jakarta: PT Rajagrafindo Persada, 2012

Nafis, Ahmadi H. Syukran. Pendidikan
Madrasah Dimensi Profesional Dan Kekinian Yogyakarta: LeksBang Presindo, 2010.

Riduwan, Dasar-Dasar Statistika, Bandung: Alfabeta. 2010.

Suwatra, I Wayan. Sosiologi Pendidikan, Yogyakarta: Graha Ilmu, 2014.

Tambak, Syahraini. Pendidikan Agama Islam Konsep Metode Pembelajaran PAI, Yogyakarta: Graha Ilmu, 2014.

Tim Dosen, Pedoman penulisan Skripsi Fakultas Agama Islam Universitas Islam Riau Pekanbaru. 2010.

Usman, Moh. Uzer. Menjadi Guru Profesional, Bandung: PT Remaja Rosdakarya, 2010. 